\title{
Local Community Life Satisfaction at Early Stage Tourist Destination
}

\author{
Fitri Abdillah, Vincent Leewellyn, Michael Yadisaputra \\ Hotel Business Program, Podomoro University \\ Corresponding Author: fitri.abdillah@ @ podomorouniversity.ac.id
}

\begin{abstract}
ARTICLE INFO
ABSTRACT

Received

7 June 2020

Accepted

31 August 2020

Available online

30 September 2020

The developing destinations are marked by increasing level of community life satisfaction. The objective of study is to identify the level of life satisfaction of local people in early stage tourist destinations. The method is a survey with a mix method analysis to justify the findings. Primary data were obtained from 6 tourism actors and local community leaders, while secondary data were obtained from official government institutions. The location of the study was two mangrove destination in North Karawang, West Java. The results showed that in the early stages of tourism destination development, the level of life satisfaction of the local community showed a high response to the subjective indicators but lower to the objective. In subjective indicators, the highest response occurs in the community's collectivity in building, but low in fulfilling personal aspects, especially awareness about the future. Local people feel relatively satisfied with their living conditions, especially family, social religious situation, and physical environment. They also view that tourism can be an alternative way out to improve economic conditions and the physical environment. Further research needs to see behavioral changes of local community to face destination development due to the increasing number of tourists.
\end{abstract}

Keywords: early stage destination, life satisfaction, community

\section{INTRODUCTION}

\section{Background}

Destination development and management is one of the major concerns of any country or any region or destination in any part of the world. The nature of the destination, resources available, hosts, the visitor's behavior and experiences and management of tourism resources http://ojs.unud.ac.id/index.php/eot optimally are extremely important research topics today (Manhas, Manrai, \& Manrai, 2016). According to (Kim, 2002), tourism also viewed as expression of human behavior. It means interaction between local community and the tourist is important factors. Once a community becomes a destination, the lives of residents in the community are affected. e-ISSN: 2407-392X. p-ISSN: 2541-0857 
Aref (2011) underlines that changes in people's life satisfaction has to be a major concern by policy makers. Destination development must support the residents to be involved in the development, planning, successful operation, and sustainability of tourism,

Destination development is the strategic planning of defined areas to support the evolution of desirable destinations for travellers, with a sole focus on the supply side of tourism, by providing compelling experiences, quality infrastructure, and remarkable services to entice repeat visitation ${ }^{1}$. It will rather related with exploitation of destination resources that caused not only economic performance, but also life satisfaction of their community. Understanding tourism development from the local resident standpoint will deepen understanding of both the long-term success and sustainability of tourist destinations (Woo, Kim, \& Uysal, 2015). The rapid growth of destination development has been powerful means of investment, creates jobs, and promotes the destination. Accordingly the life satisfaction of community should be increased too.

The impact of tourism development on local communities has been widely investigated (Khizindar, 2012; Jeon, Kang, \& E, 2014; Uysal, Sirgy, Woo, \& Kim, 2015; Abdillah, Damanik, Fandeli, \& Sudarmadji, 2015). It is shared that the support of local residents is crucial for the success and sustainability of any tourist development (Bimonte \& Punzo, 2011; Lee, 2013). Therefore tourism development should be integrated with community planning and development. This integration will guarantee the creation of harmonization among the interests of stakeholders including the local community (Abdillah, Damanik, Fandeli, \& Sudarmadji, 2015). Destination development and its connection to residents' Quality of Life (QoL) has many atention over the past few years (Bimonte, D'Agostino, Grilli, \& Pagliuca, 2019).

People realized that there are relation between residents' attitudes to tourism and residents' happiness and satisfaction with life domains. Research that focusing on well-being related with tourism has recently flourished (Pearce, 2009; Pearce, Ross, \& Filep, 2010; Rivera, Croes, \& Lee, 2016; Sirgy, Kruger, Lee, \& Yu, 2011; Bimonte, D'Agostino, Grilli, \& Pagliuca, 2019). (Kim, 2002) stated that wellbeing is associated with quality of life. Quality of life (QoL) refers to how

\footnotetext{
${ }^{1}$ https://www.destinationbc.ca/what-wedo/destination-management/destinationdevelopment/ 
individuals subjectively assess their own well-being and their ability to perform physical, psychological, and social functions $^{2}$. In the context of destination development, QoL are daily life condition of impacted community in the destination. Kim (2002) expressed development impact means perceptions of tourism (economic, social, cultural, and environmental) with residents' satisfaction with particular life domains (material well-being, community well-being, emotional well-being, and health and safety well-being) and overall life satisfaction.

As tourist destination, coastal zones (CZ) are complex areas of strategic importance at an environmental, economic, social, cultural, and recreational level. They are constantly under pressure from human occupation and overexploitation of resources, resulting in serious environmental impacts. Coastal areas have an influence on the socio-economic conditions of people who live in or around it. The coast has a high degree of demographic vitality, and a major part of coastal populations is economically dependent on marine resources (Carvalho, Ulisses, Azeiteiro, \& Meira-Cartea, 2012).

In terms of destination awareness, it has been widely appreciated that

\footnotetext{
${ }^{2}$ Department of Epidemiology and Health Statistics, School of Public Health, Southeast University, Nanjing 210009, China

http://ojs.unud.ac.id/index.php/eot
} natural resources (Sukardjo, 1993). Mangrove areas are the target of natural resource exploitation activities due to development demands. The more economic benefits gained, the heavier the burden will be. The higher the level of development, it should be the higher the benefits obtained by the community.

Karawang is a strategic location for mangrove conservation in Java. The characteristics of muddy beaches and calm waters cause mangroves grow easily. At least there are two advantages of developing mangroves on the north coast of Karawang, namely as an enrichment of tourism destinations and conservation of waters for fisheries development. Karawang tourism destination development is directed to develop five targets, namely the arrangement of tourist attractions, increased accessibility, community empowerment, and increased investment (Anonimous, 2016). The location of a mangrove destination in Karawang are Pantai Pusaka Jaya dan Pantai Sedari. As a tourism destination, the mangrove area has a significant impact on the quality of life of local people especially in increasing income in the form of fisheries and tourism 
Based on mapping of destination life cycle concept, Karawang can be categorized as early stage tourist destination. Inspired by Butler (1980) TALC, Hussin (2019) proposes that destinations are considered to evolve in six distinct phases of exploration, involvement, development, consolidation, stagnation, and decline and/or rejuvenation where each of which is characterized by a number of identifiable features. Early stage tourism destination refer to exploration and involvement phase. As Butler R. (1980) mention the early stage is characterized by small numbers of tourists. At this time there would be no specific facilities provided for visitors. The use of local facilities and contact with local residents are therefore likely to be high, which may itself be a significant attraction to some visitors.

This study aims to determine the level of community life satisfaction on the early stage tourism destination. This study wants to see whether tourists who have an impact on economic activity also have a positive impact on the level of satisfaction of local people's lives in destination. In other words how changes in quality of life occur in tourism destinations and is it true that the development of tourism destinations has an impact on changes in the quality of life of the community.

http://ojs.unud.ac.id/index.php/eot

\section{LITERATURE REVIEW}

\section{Early Stage Destination Development}

As Butler's proposed of TALC evolve in six distinct phases of exploration, involvement, development, consolidation, stagnation, and decline and/or rejuvenation. The specific characteristic of each stage of a destination lifecycle required different strategies in order for the destination planner to maintain or gain the desired position and improve the competitive advantage of the destination. In the earliest stage of destination lifecycle, the destination product and market share are usually unknown. Thus the adoptions of correct strategies are absolutely necessary in order to forestall future issues ahead. These strategies include selling new product/ services to new markets and Expand market share and build awareness among the tourist. By implementing both strategies, the destination hope to attain a strong market position before competitors enters (Cooper, 1992).

Butler R. (2011) explain the purpose of developing the model is to direct attention to the natural dynamics of the development of tourism destinations. Besides that the model also gives an overview of the general process of development as well the potential for decreases that should be avoided with appropriate interventions (planning, 
management and development). The key to the TALC concept is carrying capacity. The right intervention will ensure that various carrying capacities (economic, socio-cultural and environmental) exceeded or if possible returns to the growth phase.

\section{Life Satisfaction}

According to Gondos (2014) concept of quality of life was first used by Pigou in 1920, however, it became widespread only in the 1950s. To determine what quality of life is we cannot find a uniform definition. It occurs in the determinations that such factors are needed to the quality of life or to the increasing of it which contribute to people's social, economical and environmental welfare, therefore the improvement of these factors has to be emphasized.

Susniene \& Jurkauskas (2009) states that until now there has not been a single concept of quality of life that is universally stated and accepted. Quality of life is defined as an understanding of life satisfaction. In recent years the interest towards researching quality of life has gradually increased.With the development of quality of life-oriented strategy the experts initiated the creation of TRQL index (Tourism Related Quality of Life index) (Kovács (2007) in Gondos, 2014). The tourism-related quality of life has two http://ojs.unud.ac.id/index.php/eot parts: first, in a tourist destination the impact of tourism on the residents' quality of life. Second, a person's active participation in the tourism industry (or the lack of this) and its impact on life satisfaction. The researchers tried to map the relationship between tourism and quality of life along the following five factors: 1. visiting/visitor's motivation; 2. characteristics of travelling; 3. impact of tourism; 4. characteristics of tourism or destination; 5. travelling as assessment of activity

Sirgy, Lee, Larsen, \& Wright (1998) states that the quality of life of a person is an amalgamation of life satisfaction which includes individual subjective conditions and objective conditions in society. The objective approach represents the general quality of life of the community, while the subjective approach represents the satisfaction of the individual towards his life.

In quality of life research, one often distinguishes between the subjective and objective quality of life. Subjective quality of life is about feeling good and being satisfied with things in general. Objective quality of life is about fulfilling the societal and cultural demands for material wealth, social status and physical well-being. Morris dan Alpin (1982) put forward the concept Physical Quality of Life Index (PQLI). There are three elements included 
in the index namely: infant mortality, life expectancy, and literacy rates.

In subjective context, Kim (2002) explained that quality of life is determined by four aspects namely material, community, emotional, and health and safety. The ideal concept of quality of life is determined by an objective approach supported by a subjective approach. However, even though objective assessments are easier to do, subjective judgments dominate the discussion, given their size is the micro size of a particular area.

Table 1. Previous Research on Turism and Quality of Life

\begin{tabular}{|c|c|c|c|}
\hline $\begin{array}{l}\text { Researcher, year } \\
\text { of Research }\end{array}$ & Purposes of study & QOL measurement used & Note on result \\
\hline $\begin{array}{l}\text { Khizindar } \\
(2012)\end{array}$ & $\begin{array}{l}\text { To analyze direct effect } \\
\text { of tourism on the } \\
\text { perception of resident } \\
\text { quality of life and to } \\
\text { investigate between } \\
\text { tourism and demographic } \\
\text { information }\end{array}$ & $\begin{array}{l}3 \text { subjective indicators are adopted from } \\
\text { (Kim, 2002) to measure overall QOL. }\end{array}$ & $\begin{array}{l}\text { Social, cultural, and environmental } \\
\text { impacts } \\
\text { affect resident's quality of life and } \\
\text { demographic characteristics affect their } \\
\text { perception of tourism domains. }\end{array}$ \\
\hline $\begin{array}{l}\text { Uysal, Sirgy, } \\
\text { Woo, \& Kim, } \\
(2015)\end{array}$ & $\begin{array}{l}\text { To determine the } \\
\text { relationship between } \\
\text { perception of tourism } \\
\text { impact and community } \\
\text { stakeholder quality of } \\
\text { life }\end{array}$ & $\begin{array}{l}6 \text { subjective items are adopted from } \\
\text { previous } \\
\text { research in order to measure overall } \\
\text { quality of } \\
\text { life. }\end{array}$ & $\begin{array}{l}\text { Satisfaction with material and non- } \\
\text { material } \\
\text { life positively affect their overall quality } \\
\text { of life } \\
\text { moreover, the type of community } \\
\text { stakeholder } \\
\text { group moderate this relationship. }\end{array}$ \\
\hline $\begin{array}{l}\text { Joon, Kang, \& } \\
\text { Desmarals } \\
(2014)\end{array}$ & $\begin{array}{l}\text { To investigate influences } \\
\text { of seasonal attributes on } \\
\text { resident perception of } \\
\text { tourism impacts and } \\
\text { residents quality of life } \\
\text { in a cultural heritage } \\
\text { tourism destination }\end{array}$ & $\begin{array}{l}4 \text { subjective items are used for the resident } \\
\text { quality of life construct. }\end{array}$ & $\begin{array}{l}\text { Perceived economic benefits, environment } \\
\text { sustainability, and perceived social costs } \\
\text { positively affected residents' perceived } \\
\text { quality of life }\end{array}$ \\
\hline $\begin{array}{l}\text { Abdillah et al. } \\
(2016)^{*}\end{array}$ & $\begin{array}{l}\text { To determine the } \\
\text { relationship between } \\
\text { level of tourist } \\
\text { destination development, } \\
\text { community involvement, } \\
\text { and community quality } \\
\text { of life }\end{array}$ & $\begin{array}{c}4 \text { subjective indicators are adopted from } \\
\text { previous research }\end{array}$ & $\begin{array}{l}\text { There are significant difference between } \\
\text { the quality of life of local communities and } \\
\text { their involvement in the two phases of the } \\
\text { development of tourism destinations }\end{array}$ \\
\hline
\end{tabular}

\section{Tourism Development and Life Satisfaction}

The development of tourism research and quality of life with a series of reviews since 2012 (Uysal, Sirgy, Woo, \& Kim, 2015).

The research method is a survey research rather with a qualitative approach. However, on some information a quantitative is used to describe the information from secondary data. Given this, the characteristic of qualitative methods are considered eminently more

\section{METHOD}


suitable than those of quantitative. As qualitative is the root for interpretive paradigm, which recognises the significance of subjective experience and provide a wealth of depth of detailed information regarding the issues being investigated. The aim of the study is to understand and explain profile of the level of quality of life of local people towards the development of tourism destinations that occur.

The variables used are done by inspiring quality of life design Kim (2002), Susniene \& Jurkauskas (2009), and Abdillah, Damanik, Fandeli, \& Sudarmadji (2015) as follows:

a) Objective Indicators (Literacy number, Life Expectancy Rate, Standar of Living, Human Development Index)

b) Subjective Indicators (Happiness, Religious Atmosphere, Social Engagement, Social Capital, Hospitality Awareness)

$$
\text { Analysis of objective }
$$
measurements is carried out by tabulating time series data obtained from Central Bureau of Statistics at Karawang. Subjective measures are analyzed by judgment of interview information. Six informants were selected as members and local community leaders. Informants are determined based on length of stay in the community, role in the community, as well as knowing various information about the destination

The interviews results were analyzed by judgment to assess the level of quality of life of local people that is bad, fair, and good. The bad condition if its indicate a bad condition, irregular, and not maintained, while good condition indicate good, organized, and well-maintained conditions. Secondary data were analized by simple statistical (mean, median, mode) and compared with national standard of HDI.

\section{RESULTS AND DISCUSSION}

\section{Study Area}

This research was conducted in two locations that is Pusaka Jaya and Sedari, Karawang Regency. Both of these locations are known as mangrove tourist destinations by the local community. In 2004 Karawang had 5400 hectares of mangrove forest in 8 sub-districts, mainly Cibuaya, Cilebar and Cilamaya (Maulana, 2011). Data pada tahun 2016 menunjukkan bahwa terjadi kerusakan sebanyak 54\% dari luas mangrove tersebut. Data in 2016 shows that there was $54 \%$ of mangrove area was damage. Mangrove damage is caused by the exploitation of the surrounding community to provide their needs. Mangroves area convert to ponds, settlements, industry, beach reclamation as e-ISSN: 2407-392X. p-ISSN: 2541-0857 
tourist area. The distribution of mangrove area in Karawang Regency is as follows.

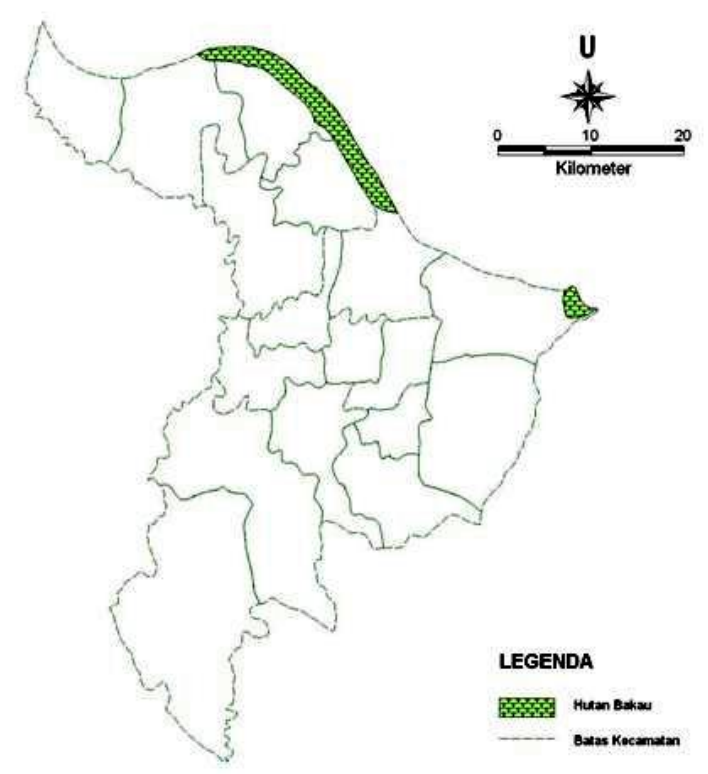

Figure 1. Distribution of Mangrove Forests in Karawang Regency (2004)

Along with community awareness about mangrove sustainability, since 1999 it began the effort to preserve mangrove forests for tourism activities. Two villages that intensively carry out conservation are Pusaka Jaya and Sedari village North Karawang. This conservation effort supported by various stakeholders, especially companies that care about preservation such as Toyota and Pertamina. The types of mangroves planted in the two regions include Rhizophora apiculata, Rhizophora mucronata, Rhizophora stylosa, Avicennia marina, Sonneratia alba, Lumnitzera racemosa, etc. There are so many obstacles in developing mangrove area such as environment pollution, flood and exploitation. Although the community is aware of the function of mangroves as coast protection, the economic needs of the community make the existence of mangroves always threatened.

The current of tourist visits is local tourist with an average of 30 group each day. This visit will significantly increase during the school holiday season or on religious holidays. The type of tourists are local tourists, most of them are families, with the purpose of the visit is refreshing to enjoy fresh air.

\section{Objective Indicator of Quality of Life}

In accordance with the objectives of the study, there are two measuring instruments used are objective and subjective measurement. Objective data obtained from secondary data as follows:

a) Literacy number

Literacy number is defined as proportion of population aged 15 years and over who has the ability to read and write simple sentences. In the current calculation, to measure the level of literacy the EYS (expected years school) number is used (BPS, 2019).

b) Life Expectancy Rate

Life Expectancy Rate (LER) is defined as the average number of years a person will live who have succeeded in reaching that age in the situation of death prevailing in the community (BPS, 2019). LER is 
part of the Human Development Index as an objective measure of the quality of human life

c) Standard of Living (Income)

According to Indonesia's Law number 11 of 2009 standard of living is a condition of meeting material needs in order to live properly and be able to develop themselves, so they can carry out their social functions. Standard of living is represented by income. According to BPS (Central Bureau of Statistics) income is all money received in both the formal and informal sectors which is calculated within a certain period. Sajogyo (1977) stated that a high level of income will provide greater opportunities for households to choose food that is better in quantity and quality of nutrition. Low income will cause low quality of family nutrition.

The following data is the human development data of Karawang areas:

Table 2. Objective Indicators of Life Satisfaction

\begin{tabular}{ccccc}
\hline Year & HDI & LER & EYS & Income (IDR) \\
\hline 2011 & 64.58 & 71.38 & 10.76 & 94.41 .37 \\
\hline 2012 & 65.97 & 71.41 & 10.92 & 95.24 .89 \\
\hline 2013 & 66.61 & 71.44 & 11.08 & 96.71 .03 \\
\hline 2014 & 67.08 & 71.45 & 11.31 & 97.55 .43 \\
\hline 2015 & 67.66 & 71.55 & 11.64 & 96.78 .31 \\
\hline 2016 & 68.19 & 71.60 & 11.69 & 10.216 .85 \\
\hline 2017 & 69.17 & 71.64 & 11.85 & 10.379 \\
\hline 2018 & 69.89 & 71.69 & 11.96 & 10.703 \\
\hline $\begin{array}{l}\text { National } \\
\text { Standard }\end{array}$ & 70.05 & 71.39 & 8.17 & 11.06 \\
\hline
\end{tabular}

Source: BPS Karawang, 2019

\section{Subjective Indicators of Quality of Life}

Subjective data from the interview consist of:

a) Happiness

Happiness is general psychological well-being or satisfaction with life as a whole (Santrock, 2002). Happiness will arise and be experienced if someone's needs and desires can be fulfilled at a certain time.
The results showed that the local community both in Sedari and Pusakajaya were happy with their life. The happiness is determined by their income, absence of ill, and education especially for their children. Tourists cause them to create business opportunities from mangroves. The main income of the people of Sedari Village is fishermen and fishpond entrepreneurs. Increasing the number of tourists causes 
them to be able to sell the results of fishermen and fishponds at better prices

People's happiness is also determined by the existence of good relations with the surrounding environment. Pusaka Jaya Village people are happy by working together to maintain mangroves from their natural threats. The threats that often occur are pollution and tidal waves that cause abrasion. Since 1999 there have been at least 4 abrasions which damaged mangroves already planted before.

b) Religious Atmosphere

Religious atmosphere is subjective conditions of the individual towards the level of fulfillment of the needs of the religious condition, God's justice and respect for God's creation. The results showed that the level of religious appreciation could be seen from the many houses of worship in Pusaka Jaya and Sedari. The entire house of worship was built independently by the community. The house of worship implies the need of the people to worship God. The entire community of Sedari and Pusaka Jaya villages are Muslim.

The appreciation of religious values is felt during the Islamic holidays. Nevertheless the community did not leave the traditional belief that apply from generation to generation. "Sedekah Laut" ceremony is a traditional ceremony that is still valid to welcome the sea season and http://ojs.unud.ac.id/index.php/eot give thanks for catching of fish. Although the prayer in this ceremony is in accordance with Islam, its implementation is not in accordance with Islamic teachings.

The community is also very open with their respective religious behavior. The tolerance level is shown by permissively the circulation of liquor. This happened because the people in both villages were fishing communities who were accustomed to drinking liquor. The most important in reltionship among community are not interfere with each other among the members of the community.

The community is also aware of religious education for the community, especially children. There are several basic religious education facilities at the level of kindergarten. This educational institution is managed by the community in a cooperative manner by bringing in religious teachers.

c) Social Harmony

Harmony is defined as the attitude of a person to allow freedom to others and recognize differences as recognition of human rights. The local people of Sedari and Pusaka Jaya have a very good harmony with a high concern for the environment. This is indicated by the entire social activities of the village carried out in mutual cooperation (gotong royong). Village infrastructure improvements for example, as long as there is no government 
assistance, the community does it themselves. In Pusakajaya Village road infrastructure is often affected by tidal waves, while in Sedari floods occur during the rainy season.

The existence of a village program that drives the community in waste and mangroves management is also an indication of a high level of harmony. In Pusaka Jaya Village, community awareness of waste and mangrove management is carried out independently, whereas in Sedari Village although the mangrove area is Perhutani's (national forest company) land, the community is involved in mangrove conservation.

d) Hospitality Awareness

Hospitality Awareness interpreted as the relationship between guests and the community in hospitality activities. In general the community is a friendly and very accepting community, because they are Sundanese, hospitality in receiving guests is Sundanese style.

The people of Pusaka Jaya and Sedari are aware of the importance of serving tourists as customer. However, according to the Sundanese local character, there are various shynesses that often cause interactions to be hampered. The natural behavior of people who strongly support hospitality is the level of honesty. Honesty causes an excellent level of village security. In general, although the ability of services http://ojs.unud.ac.id/index.php/eot is still low, public awareness to be involved and serve is very good. This is reflected in the welcoming hospitality, always smiling, and the price offered is relatively fair. Excellent service training programs are needed to improve their ability to serve tourists.

e) Social Capital

Social capital is a resource that is owned by the community in the form of norms or values that facilitate the community to build community. Coleman (1999) states that social capital is the ability of people to work together, in order to achieve shared goals, in various groups and organizations. In terms of social capital the people of both villages have pride in the village's potential. The community of both villages has social cohesiveness that is able to be a driving force in the development of tourist destinations. Tourism is realized is a new opportunity for the community to increase income.

Even though there are no informal leaders in the two villages, it seems that formal figures who collaborate with youth are able to become the dynamic development. The development in Sedari Village is accelerated with the village head who has a vision of tourism and is fighting for infrastructure improvements. In contrast to Sedari, Pusaka Jaya Village has a youth group that is seriously fighting for consistent mangrove development. Very e-ISSN: 2407-392X. p-ISSN: 2541-0857 
strong social capital in both villages is a high spirit of progress and development.

\section{Discussion}

Analysis of the findings was carried out in accordance with the objective of the study, to measure the quality of life of local community and determine which variable is the most prominent. The analysis used is descriptive personal judgment, as follows:

Table 3. Indicators and Parameter of Life Staisfaction

\begin{tabular}{|c|c|c|c|}
\hline $\begin{array}{c}\text { Life } \\
\text { satisfaction } \\
\text { indicators }\end{array}$ & Parameters & $\begin{array}{c}\text { Parameter,s } \\
\text { value }\end{array}$ & Scale \\
\hline \multirow{4}{*}{$\begin{array}{l}\text { Objective } \\
\text { indicators }\end{array}$} & $\begin{array}{l}\text { Human } \\
\text { development } \\
\text { index }\end{array}$ & $\begin{array}{l}\text { Below from } \\
\text { national HDI }\end{array}$ & Fair \\
\hline & $\begin{array}{l}\text { Life } \\
\text { expectancy }\end{array}$ & $\begin{array}{l}\text { Higher than } \\
\text { national } \\
\text { standards }\end{array}$ & Good \\
\hline & $\begin{array}{l}\text { Early Years } \\
\text { School }\end{array}$ & $\begin{array}{l}\text { Higher than } \\
\text { national } \\
\text { standards }\end{array}$ & Good \\
\hline & Income & $\begin{array}{l}\text { Lower than } \\
\text { national } \\
\text { standards }\end{array}$ & Fair \\
\hline \multirow{5}{*}{$\begin{array}{l}\text { Subjective } \\
\text { inficators }\end{array}$} & Happiness & $\begin{array}{l}\text { The } \\
\text { community is } \\
\text { happy with } \\
\text { tourism }\end{array}$ & Good \\
\hline & $\begin{array}{l}\text { Religious } \\
\text { atmosphere }\end{array}$ & $\begin{array}{l}\text { Stable } \\
\text { religious } \\
\text { atmosphere }\end{array}$ & Good \\
\hline & $\begin{array}{l}\text { Social } \\
\text { harmony }\end{array}$ & $\begin{array}{l}\text { There are no } \\
\text { social } \\
\text { conflicts and } \\
\text { safe village } \\
\text { conditions }\end{array}$ & $\begin{array}{l}\text { Very } \\
\text { Good }\end{array}$ \\
\hline & $\begin{array}{l}\text { Hospitality } \\
\text { awarenss }\end{array}$ & $\begin{array}{l}\text { High level of } \\
\text { service } \\
\text { awareness }\end{array}$ & Good \\
\hline & $\begin{array}{l}\text { Social } \\
\text { capital }\end{array}$ & $\begin{array}{l}\text { Having a } \\
\text { strong social } \\
\text { capital that is } \\
\text { mutual } \\
\text { cooperation }\end{array}$ & $\begin{array}{l}\text { Very } \\
\text { Good }\end{array}$ \\
\hline
\end{tabular}

http://ojs.unud.ac.id/index.php/eot
This study investigates the relationship between tourism development and life satisfaction from the perspective of residents. Happiness is an important aspect of life satisfaction is more likely to adopt activities and behaviors that benefit societies (Diener, 2000). The results showed that in the early stages of tourism destination development, the subjective indicators is higher than the objective. Hal ini mengindikasikan bahwa masyarakat merespons secara genuine terhadap perkembangan pariwisata.

HDI is an objective measurement of the quality of life of a community. This measurement consists of three main parameters life expectancy, income, and literacy number. These three components are recognized internationally as a measurement of the quality of life. Ngoo \& Tey (2019) stated that although HDI has been adopted as a measure of development, a cursory review of the literature indicates that there has been no analysis on the association between HDI and overall life satisfaction whether it influence happiness. The results showed an indication of an inverse relationship between happiness and HDI. The level of HDI which is below the national standard does not affect the level of happiness that occurs. This can happen because the community believes that so far it can still provide daily needs and socialy needs then they remain happy. 
Happiness matters to the individual and to society. Therefore, it behooves destination managers to monitor happiness patterns. Traditionally, monitoring mainly considers material indicators such as GDP, consumer confidence, life expectancy, education output, etc (Ngoo \& Tey, 2019). This study indicates that the focus on assessing well-being based on increased material wealth (e.g. GDP, consumer confidence, etc.) does not fully capture happiness patterns. In other words, destination managers who only consider, for example, jobs and income that tourism development provides may miss valuable information about what truly enhances happiness. For example, objective data may indicate that more people are working two jobs and are sleeping less. Government intervention may mandate higher wages and more social security benefits. However, well-being indicators may suggest that workers are less happy with their work and family.

In subjective indicators, the highest response occurs in the community's collectivity in building, but low in fulfilling personal aspects, especially awareness about the future. Among the various aspects of quality of life, aspect social harmony and social capital have higher respons than others. In general, local people feel relatively satisfied with their living conditions, social religious situation, http://ojs.unud.ac.id/index.php/eot and environment. The community views that tourism can be an alternative way to improve economic conditions and the physical environment.

\section{CONCLUSION}

\section{Conclussion}

The conclusions obtained from this study are as follows:

a) Both of study location are newly developed village as a tourist destination with mangrove forest as main attractions. Based on Butler's TALC, they are included in the initial development phase of tourist destinaton

b) Objectives measurement indicate that all of parameters good grades (higher than national standards) except HDI. Overall, the objective quality of life of local people is in good condition.

c) Subjective measurements consist of level of happiness, religious atmosphere, community harmony, awareness of hospitability, and social capital indicate are in very good condition.

Based on indication of their life satisfaction, both of village are ready to be higher level of tourist destination. The general conclusion is the level of life satisfaction of local people in Sedari and Pusaka Jaya is good. Both of villages is worthy to be tourist destination. 


\section{Future Research}

The results of the study are qualitative descriptions of the profile of local communities in relation with their acceptance of tourism activities. A high level of life satisfaction indicates that the community is in a good situation for tourism development. Further research needs to see behavioral changes of local community to face destination development due to the increasing number of tourists.

\section{ACKNOWLEDGEMENT}

We would like to thank to Hotel Business Program Podomoro University and Directorate General of Higher Education in supporting for our research.

\section{REFERENCES}

Abdillah, F., Damanik, J., Fandeli, C., \& Sudarmadji, S. (2015). Perkembangan Destinasi Pariwisata dan Kualitas Hidup Masyarakat Lokal. MIMBAR: Jurnal Sosial dan Pembangunan, 31(2), 339-350.

Anonimous. (2016). Rencana Induk Pengembangan Keariwisataan Daerah Karawang 2016-2026. Karawang: Pemerintah Daerah Kabupaten Karawang.

Aref, F. (2011). The Effects of Tourism on Quality of Life: A Case Study of Shiraz, Iran. Life Science Journal, Volume 8, Issue 2, 26-30.
Bimonte, S., D'Agostino, A., Grilli, G., \& Pagliuca2, M. (2019). Tourist season and residents' life satisfaction: Empirical evidence from a longitudinal design in a Mediterranean destination. International Journal Tourism Research, 1-11.

BPS. (2018). Karawang dalam Angka tahun 2017. Karawang: Biro Pusat Statistik.

BPS. (2019). Karawang dalam Angka tahun 2018. Karawang: Biro Pusat Statistik.

Butler, R. (1980). The Concept of a Tourist Area of Life Cycle of Evolution: Implications for Management of Resource. Canadian Geographer Volume 19 No.1, 5-12.

Butler, R. (2011). Tourism Area Life Cycle. Woodeaton, Oxford, OX3 9TJ: Contemporary Tourism Reviews, Goodfellow Publishers Ltd.

Carvalho, S. C., Ulisses, F. A., Azeiteiro, U. M., \& Meira-Cartea, P. A. (2012). Sociocultural and Educational Factors in the Sustainability of Coastal Zones. Management of Environmental Quality: An International Journal, Vol. 23 Iss 4, $362-382$.

Coleman, J. (1999). Sosial Capital in the Creation of Human Capital. Cambridge : Mass. 
Cooper, C. (1997). The Contribution of Life Cycle Analysis and Strategic Planning to Sustainable Tourism. In S. Wahab, \& J. J. (Eds), Tourism, Development and Growth (pp. 7085). New York: Routledge.

Gondos, B. (2014). Relationship between Tourism and Quality of Life Researches at Lake Balaton. International Conference of Management and Knowledge Learning (pp. 880-887). Portoroz, Slovenia: Make Learn.

Hussin, N. Z. (2019). Tracing the Malaysia Tourism Lifecycle and Strategy Assessment from the First Malaysia Plan to Ninth Malaysia Plan. International Journal of Business and Social Science Vol. 5 No. 3, 161-168.

Joon, M., Kang, M., \& Desmarais. (2014). Residents' perceived quality of life in a cultural-heritage tourism destination. Applied Research in Quality of Life.

Khizindar, T. M. (2012). Effects of tourism on residents' quality of life in Saudi Arabia: an empirical study. Journal of Hospitality Marketing \& Management, 617-637.

Kim, K. (2002). The effects of tourism impacts upon Quality of Life of residents in the community. Blacksburg, Virginia: Virginia Polytechnic Institute and State University.
Manhas, P. S., Manrai, L. A., \& Manrai, A. K. (2016). Role of Tourist Destination Development in building its rand Image: A Conceptual Model. Journal of Economics, Finance and Administrative Science, 1-5.

Maulana, R. F. (2011). Kerusakan Hutan Mangrove Di Pesisir Karawang. Bandung: Magister Studi Pembangunan ITB.

Morris, M., \& Alpin, M. (1982). Measuring the Condition of India's Poor. New Delhi: Promilla Co. Publisher.

Ngoo, Y. T., \& Tey, N. P. (2019). Human Development Index as a Predictor of Life Satisfaction. Journal of Population and Social Studies, Volume 27 Number 1, 70 - 86.

Pearce, P. L. (2009). The relationship between positive psychology and tourist behavior studies. Tourism Analysis, 14(1), 37-48.

Pearce, P., Ross, G., \& Filep, S. (2010). Pearce, P., Ross, G., Tourists, tourism and the good life. New York: Routledge.

Rivera, M., Croes, R., \& Lee, S. H. (2016). Tourism development and happiness: A residents' perspective. Journal of Destination Marketing and Management, 5, 5-15.

Sajogyo. (1977). Garis Miskin dan Kebutuhan Minimum Pangan. Bogor: Lembaga Penelitian Sosiologi Pedesaan (LPSP). IPB. 
Santrock, J. (2002). Life Span Development (Perkembangan Masa Hidup, Jilid 2, Penerjemah: Chusairi dan Damanik). Jakarta.: Erlangga.

Sirgy, M. J., Kruger, P. S., Lee, D.-J., \& Yu, G. B. (2011). How does a travel trip affect tourists' life satisfaction? Journal of Travel Research, 50(3), 261-275.

Sirgy, M. J., Lee, D. J., Larsen, V., \& Wright, N. (1998). Satistfaction with Material Possession and General Wellbeing: The Role of Materialism. Journal of Consumer Satisfaction, Dissatisfaction and Complaining Behavior Volume 11, 103-118.

Sukardjo, S. (1993). The Present Status of the Mangrove Forests in the Northern Coast of West Java with Special Reference to the Recent Utilization. Southeast Asian Studies, Vol. 31, No.2, 141-157.

Susniene, D., \& Jurkauskas, A. (2009). The Concepts of Quality of Life and Happiness - Correlation and Differences. Inzinerine EkonomikaEngineering Economics Volume 1, 58-66.

UNWTO. (2010). UNWTO Tourism Highlight 2010 Edition. New York: UNWTO Publications Department.

Uysal, M., Sirgy, M. J., Woo, E., \& Kim, H. (2015). Quality of Life (QOL) and Wellbeing Research in Tourism. Tourism Management, 1-18.
Waryono, T. (2000). Keanekaragaman Hayati dan Konservasi Ekosistem Mangrove. Jakarta: Jurusan Geografi FMIPA-UI.

Woo, E., Kim, H., \& Uysal, M. (2015). Life satisfaction and support for tourism development. Annals of Tourism Research, 50, 84-90. 